Article

\title{
Can Hindrance Stressors Change the Nature of Perceived Employability? An Empirical Study in the Hotel Industry
}

\author{
Nazanin Naderiadib Alpler ${ }^{1, *(D)}$ and Huseyin Arasli ${ }^{2}(\mathbb{D}$ \\ 1 Faculty of Tourism, Eastern Mediterranean University, TRNC, Via Mersin 10, Gazimagusa 99628, Turkey \\ 2 Norwegian School of Hotel Management, University of Stavanger, 4036 Stavanger, Norway; \\ huseyin.arasli@uis.no \\ * Correspondence: nazanin.naderiadib@emu.edu.tr
}

Received: 30 August 2020; Accepted: 11 December 2020; Published: 17 December 2020

check for updates

\begin{abstract}
This empirical study aims to design and test a research model that investigates the effect of job insecurity as a moderator of the relationships between perceived employability and employee well-being (work engagement). It also measures the impact of perceived employability on work engagement. Data were gathered from full-time frontline workers employed in five-star hotels in Northern Cyprus to test the study variables; the partial least square structural equation model (PLS-SEM) was applied and supported the research hypotheses. In line with the study predictions and findings from previous literature, perceived employability was found to have a significant positive impact on work engagement. The result revealed that, as a hindrance stressor, job insecurity negatively affects the relationship between perceived employability and work engagement. The findings of this study provide some insights concerning employability's importance as well as influencing factors on employees' job selection and their attitudes during job performance in the organizations. The knowledge gathered in this research is a source for stressing the value of employability in developing professional skills and professional involvement, as well as for reducing the perception of job insecurity, especially in the tourism industry, which has a delicate and sensitive structure. The implications of the empirical findings are discussed and future research directions are offered.
\end{abstract}

Keywords: perceived employability; job insecurity; work engagement; frontline employees; Northern Cyprus

\section{Introduction}

The definition of employability is of importance in meeting the instability demanded by the industry, in growing an employee's professional commitment, and in raising the perception of work insecurity, particularly in the fragile and sensitive structure of the tourism sector [1]. Employability is an employee's awareness of his or her possibilities to attain a new job. It is an individual's work-related adaptability that enhances his or her ability to find and use job and career opportunities within or outside the current workplace [2].

It has also been conceptualized in existing literature as a subjective measure that concerns the beliefs of a person and how easy it is to find new jobs. Employability is dependent on specific circumstances, context, and time [3]. Employability has a range of significant consequences for the well-being of workers, and thus, further research is required to define the procedures, effects, and limits of the requirements for organizational performance [4]. Besides, rapid globalization and technological advances have become a reality in today's life. Therefore, companies need to concentrate on adaptation and employee involvement to stay ahead of their rivals. Fostering sustainable workplace employment 
is also crucially required to adjust and successfully react to environmental changes [5]. The economy of Northern Cyprus is dominated by the service sector, which includes trade, education, and tourism. In particular, the tourism and hospitality sector is at the forefront of development in the country [6]. Therefore, in this competitive market environment, especially for the tourism and hospitality sector, the main concern is to be able to deliver high-quality services to customers. Finding and retaining skilled and qualified employees who can provide frontline service jobs are priorities for hospitality organizations [7]. With this realization, hospitality managers need to provide their employees with sufficient support and peace of mind, which can motivate them to show high-quality performance in the workplace. If those employees experience workplace stress and unjust behaviors or if they are not assured about their job security, this will not be to the advantage of the organization [8]. Job insecurity has been causing a stir among researchers [9-11] because the outcomes of perceived job insecurity are often costly to service organizations in several aspects.

More research attention has lately been given to the connection between employability and the subjective well-being of workers, such as through work engagement and job satisfaction [3]. "Work Engagement" refers to "a positive, fulfilling, work-related state of mind that is characterized by vigor, dedication, and absorption" (Schaufeli et al., 2002, p. 74) [12].

In light of the information given above, the primary objective of this study is to propose and test a conceptual model that evaluates work engagement as a positive outcome of perceived employability via the moderating effect of job insecurity. According to the literature, perceived employability helps workers to cope with job insecurity [4]. Employability stands with the perception of job insecurity, which is a leading factor in organizational psychology and the labor market. Even though the beneficial association between perceived employability and employee well-being (work engagement) has been well known [13], it is conceivable that the attributes of these relationships may be decided by certain prospective moderators like job insecurity.

Described as workers' awareness of possible forced work cuts [14], the development of job insecurity has been well known to be strongly related to perceived employability [15,16].

As a hindrance stressor, job insecurity has the potential to impede employees' learning skills, development, and progress [17]. This work thus not only describes the boundary state of perceived employability concerning the performance of employees but also unravels the relative functions of perceived employability and job insecurity.

Moreover, most of the recent employability research has been performed in Western countries, where the employability concept was focused on the work background of staff. However, some of these results might not be generalizable to other countries because of cultural and systemic distinctions. As such, there is no knowledge about the accuracy of these works in different regions of the world.

We undertook this research in Northern Cyprus, which can provide fresh insights into this problem. Our study also used remedies, such as time-lagged data collection for controlling common method variance in the job insecurity research, to reduce the risk [18].

The need to investigate the above-alleged relationships and to answer the question of what an organization can do to diminish the effects of job insecurity in a touristic Mediterranean island context cannot be underestimated. By understanding frontline employees' motivations to have an improved commitment and performance, researchers and practitioners can develop guidelines that organizations may use to avoid or reduce job insecurity.

\section{Literature Review and Hypotheses}

\subsection{Perceived Employability: Definition}

The definition of employability was first used in the early twentieth century. This was focused on the dichotomy of "employable" individuals (capable and eager and/or wanting to work) and "unemployable" individuals (unable to work and who needed help). 
According to [19-22], employability is an employee's knowledge of his or her prospects for a new career. This is an individual's work-related adaptability that improves his or her ability to discover and take advantage of job and career opportunities inside or outside the current workplace. However, it is the worker's understanding of potential employment prospects, either with the current employer or with another employer. Such perspectives and understanding are focused on both human and contextual factors. Human factors include human capital (educational level or training), social capital (connections and networks), and adaptability [23,24]. Contextual factors, on the other hand, are pressure problems, such as unemployment or labor market demands [25]. These variables can predict workers' perceptions of available employment [26].

\subsection{Perceived Employability: Associations with Work Engagement}

To maintain employability, individuals need to be able to respond to endless changes. Factors such as globalization and the rapid growth and development of technology have had an impact on the types of skills and abilities required to be successful in today's organizations [27]. The emphasis of most companies is on the acquisition of skilled employees who possess specialized skills and who can continue to do so [28]. With the transition to knowledge work, the values of using talents and continuing to grow, improve, and enhance one's skills, abilities, and talents are core components of career and personal success that have a direct effect on employability [29].

Most scholars define employability as a workplace benefit, causing control over one's daily life and, in a wider context, over one's career. Control in this interpretation is close to the concept of resources illustrated in common work-related theories and organizational psychology, such as the Job Demands-Resources (JD-R) model [30,31]. The fundamental idea is that resources are positively linked to employment-related and general well-being and has received substantial support from the JD-R model. Considering that (perceived) employability is a human resource, it follows that (perceived) employability is positively linked to employee well-being. It has also been confirmed that workers who feel 'closed up' in jobs that they do not want and that experience challenges in seeking new employment are likely to be less employable [32,33].

As a desirable result for the workforce, work engagement is defined as "a positive, fulfilling, work-related state of mind that is characterized by vigor, dedication, and absorption" [34]. A host of work engagement research has employed the JD-R paradigm as an explanatory tool [35]. The model indicates that dedication to work derives from the motivating importance of two categories of resources: employment resources, which contribute to various facets of work that are realistic for achieving work goals, mitigating task demands, and fostering personal growth and development, and personal resources. There are facets of self-reliance that are usually related to resilience and the willingness to successfully monitor and affect one's atmosphere (e.g., self-efficacy, self-esteem dependent on the organization, motivation, and mental stability) [36].

As a type of personal resource, perceived employability is predicted to be positively associated with work engagement. Empirically, reference [13] stated that there is a positive relationship between perceived employability and work engagement. Employability has been claimed to provide people with a sense of autonomy and to make them more likely to achieve participation at work. We, therefore, suggest the following hypothesis:

Hypothesis 1 (H1). Perceived employability is positively related to work engagement.

Employability is linked to the sense of job insecurity and is a leading influence in occupational psychology and the labor market. Currently, according to the literature, perceived employability helps employees deal with workplace uncertainty, which is known as job insecurity $[37,38]$, in such a manner that employability increases the sense of being in charge of one's life, which, in turn, decreases the negative consequences of work instability [39]. This viewpoint reflects visions from studies on the Job Demands-Resources model [40]. 
Job demands refer to the aspects of a career that workers perceive as oppressive, such as workplace instability. Job resources boost qualities that encourage professional growth and learning-attributes that may contribute to higher levels of employability. Job resources are known to be "effective in the achievement of work goals, but also the reduction of the health-related issues of job demands."

Employability was found to be one of the possible antecedents of job insecurity $[21,38]$. High-employability employees were contrasted to low-employability employees in one study and were less likely to suffer workplace dissatisfaction.

Managers should recommend jobs with a reasonable degree of protection to recruit and maintain extremely productive workers that can quickly pursue alternate jobs in the case of unfavorable working conditions. It was claimed by Schaufeli (1992) [12] that employees with lower academic levels are more prone to facing job insecurity than highly qualified workers. They also assumed that the standard of academic level should be a measure of employability [37,40].

Moreover, employees are expected to look for employment security rather than job stability, which means that employees establish employment stability by moving across organizational boundaries and from one job to the next, rather than staying within a single organization or job [41]. In this regard, employment security is conditioned by employees' employability [42]. They concluded that highly employable employees are likely to face less job insecurity. Again, it has been suggested by researchers that employability will possibly decrease the likely unfavorable consequences of job insecurity. It is hypothesized that:

Hypothesis 2 (H2). Perceived employability is negatively related to job insecurity.

\subsection{Moderating Role of Job Insecurity}

Hindrance stressors have the potential to interrupt the development, progress, and progression of workers. Such stressors obstruct their progress toward the accomplishment of objectives [17]. According to Wang et al. (2015) [43], “ ... job-insecure employees are not able to be fully engaged at work, because they are concerned about their job outcomes. Instead, they will experience greater anxiety, anger, or frustration ... , but less positive affect ... " Consequently, it is apparent that job insecurity impedes employees' work engagement. While we have concluded that perceived employability is positively linked to work engagement, it is conceivable that the characteristics of these relationships could be dependent on certain prospective moderators [4]. One of those possible moderators is job insecurity, which refers to "the perceived stability and continuance of one's job as one knows it" [44] (p. 452). This represents the individual opinion of an employee as to whether the ideal aspects of his or her work are intact and whether or not he or she should choose to do it. People with poor levels of job security tend to feel uncertain regarding the potential availability of employment in the future. Perceptions of job insecurity may have an effect not just on the cognitive well-being of employees, but also on their own [34,45].

Based on the degree of job insecurity, people's responses to perceived employability can differ. Specifically, we speculate that a favorable correlation between perceived employability and work engagement will diminish as individuals feel more uncertain regarding their jobs. Such a hypothesis should be interpreted from the point of view of investing parties $[4,46]$. Perceived employability is dependent not only on previous corporate commitment (e.g., training) but also on the comprehensive involvement of employees in their human capital (e.g., education). As a consequence, employees typically anticipate their investments to be compensated by businesses, and job security may be a benefit of that nature [47]. If it is not, then highly employable workers can believe they are not adequately paid for their contributions and thus suffer a psychological violation of the contract. This has certain adverse effects, such as decreased loyalty, organizational engagement, job satisfaction, and motivation at work [48]. According to a different study, the connection between perceived employability and optimal functioning (i.e., in-role success and supportive behavior) is much less than the rate of perceived job insecurity [49]. The present research would proceed to position the 
relationship between perceived employability and employment-related well-being in the sense of perceived job insecurity. We, therefore, suggest the following hypothesis:

Hypothesis 3 (H3). Job insecurity is negatively related to work engagement.

Hypothesis 4 (H4). When the job insecurity level is high, the positive affiliation between perceived employability and work engagement is reduced.

The conceptual model displaying the above-mentioned hypothesized relationships can be seen in Figure 1.
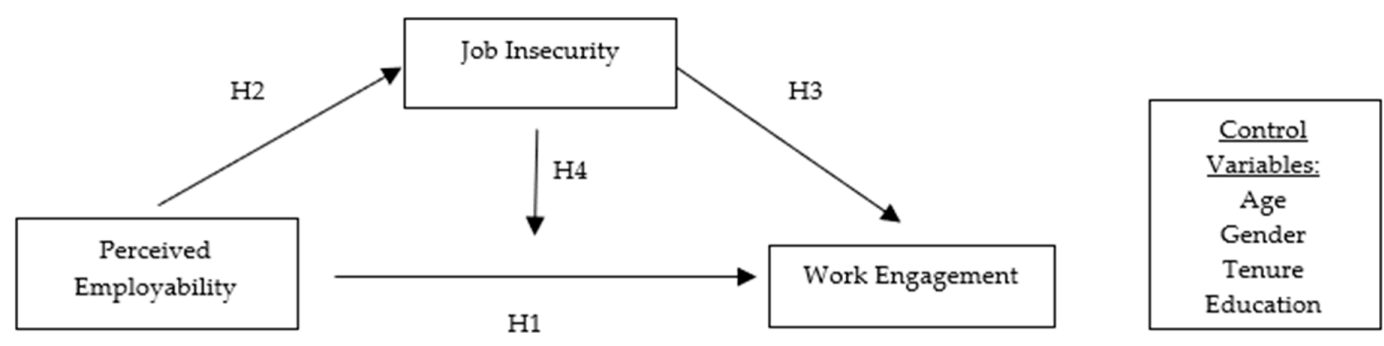

Figure 1. Conceptual model.

\section{Method}

\section{Sample and Procedure}

The suggested hypothesis was tested based on data gathered from full-time frontline workers at five-star hotels throughout Northern Cyprus. The research group included frontline employees who spend much of their time interacting with clients' queries in a face-to-face manner. This includes employees who work as front desk staff, door attendants, reception clerks, bell attendants, concierges, and customer service representatives. According to details obtained from the Ministry of Tourism, Culture, and the Environment at the time of this research, there were 17 five-star hotels situated in Northern Cyprus. The research group approached the administrations of all five-star hotels with a letter containing the purpose of the study and asking for permission for data collection. As result, the management of 12 five-star hotels approved their contributions to the empirical study.

Moreover, following the procedures given by Podsakoff et al. (2003) regarding common method bias [18], a major risk that leads to the error of measurement, which, in consequence, can improve or devalue the correlations observed between research variables [50,51], we used phase distinction by adding a time gap of two weeks between the study variables. Two separate questionnaires were used for this research: the Phase I and Phase II questionnaires. The Phase I questionnaire included the perceived employability and job insecurity variables (predictor and moderator variables). The Phase II questionnaire consisted of work engagement variables, as well as items related to control variables, like respondents' age, gender, education, and organizational tenure. The employees were instructed to self-administer the questionnaire, to place it in an envelope, and to submit it to the research team.

The questionnaire was considered to be suitable for data collection depending on the findings of a pilot study performed with 15 employees. Approximately 216 questionnaires were given to frontline workers after approval was received from the hotel management. Besides, a corresponding letter specifically stating the purpose of the survey and the confidentiality of the respondents' profiles was added to the copies of each questionnaire. Out of the 216 copies distributed, 198 questionnaires were received in a two-week time period. As a result of missing data, 13 questionnaires were rejected, leaving 185 usable questionnaires for further analyses with a response rate of $85 \%$, which is a remarkable number.

Out of the 185 questionnaires, $68 \%$ of the respondents were men, while the other $32 \%$ were women. Most of them appeared to be adults between their mid-20s and mid-40s, such that the elderly 
participants accounted for only about $6 \%$. Among the participants, $45 \%$ were high school leavers or those with high school diplomas, $32 \%$ were university graduates, and the remaining group had either a primary school leaving certificate or a secondary school certificate. A good number of the participants, $35 \%$, had worked in the same organization for two to four years, and another $28 \%$ had between 5 and 7 years of tenure. Remarkably, almost $29 \%$ of the 185 respondents had working tenure in the same organization of 11 years or above, while just a small amount of the $8 \%$ were new and had served for a year or less.

\section{Measurement}

To measure perceived employability, a four-item scale used by De Cuyper et al. (2011b) was adopted [52] (e.g., "I am optimistic that I would find another job if I looked for one", "I could easily switch to another employer if I wanted to"). Seven items from Hellgren and Sverke (2003) [14] were used to measure job insecurity (e.g., "There is a risk that I will have to leave my present job", "I am worried about having to leave my job before I would like to"). For measuring work engagement, this study utilized the shortened version of the Utrecht Work Engagement Scale developed by Schaufeli, Bakker, and Salanova (2006) [53]. This scale consisted of nine items (e.g., "At my work, I feel bursting with energy", "I am enthusiastic about my job"). All 20 items representing the study variables, together with control variables (age, gender, education, organizational tenure), were gauged on Likert scales of five points, from 1 indicating strongly disagree to 5 denoting strongly agree. All items in Phase I and Phase II questionnaires were originally prepared in English and then translated into Turkish through the back-translation method of Parameswaran and Yaprak (1987) [54]. Consistently with the current literature, the potential effects of age, gender, organizational tenure, and education on the study relationships were controlled. However, the results revealed that the aforementioned variables did not confound the statistical results.

\section{Results}

\subsection{Measurement Results}

The measuring model necessitates the determination of convergent validity, the reliability of internal consistency and continuity, the differential validity, and the corresponding validity of the item [55]. The reliability of internal consistency applies to all objects being evaluated under the same definition [56]. Cronbach's alpha (CA) and composite reliability (CR) are used as internal performance estimators in management studies [57]. The CR was selected to assess the internal accuracy of the measures undertaken in the present report. The description in this study using CR was established as a rule of thumb according to Bagozzi and Yi (1988) [58]. Additionally, the CR must be more than 0.70, as recommended by Hair, Ringle, and Sarstedt (2011) [59]. The results of the CR, AVE, and CA are shown in Table 1. The levels for each latent construct in the AVE must have values of 0.50 or more to reach acceptable convergent validity according to Chin (1998) [60]. All values in our research met the commonly accepted cut-off criteria $(>0.50)$.

Table 1. Item loadings, construct reliability, and validity.

\begin{tabular}{ccccccc}
\hline Construct & Items & Loadings & AVE & CR & Alpha & VIF \\
\hline Employability & & & 0.61 & 0.86 & 0.782 & \\
& EM1 & 0.814 & & & & 2.038 \\
& EM2 & 0.877 & & & & 2.486 \\
& EM3 & 0.826 & & & & 1.928 \\
& EM4 & 0.573 & & & & 1.351 \\
\hline Job Insecurity & & & 0.639 & 0.876 & 0.817 & \\
& JS1 & 0.764 & & & & 2.154 \\
& JS2 & 0.85 & & & & 2.514 \\
& JS3 & 0.805 & & & & 1.497 \\
& JS4 & 0.776 & & & & 1.475 \\
\hline
\end{tabular}


Table 1. Cont.

\begin{tabular}{ccccccc}
\hline Construct & Items & Loadings & AVE & CR & Alpha & VIF \\
\hline Work Engagement & & & 0.631 & 0.939 & 0.926 & \\
& WE1 & 0.847 & & & & 3.028 \\
& WE2 & 0.869 & & & & 3.038 \\
& WE3 & 0.854 & & & & 3.028 \\
& WE4 & 0.859 & & & & 2.267 \\
& WE5 & 0.728 & & & & 1.886 \\
& WE6 & 0.673 & & & & 2.988 \\
& WE7 & 0.806 & & & & 3.408 \\
& WE8 & 0.780 & & & & 3.420 \\
\hline
\end{tabular}

\subsection{Discriminant Validity}

Once the values of the variables are bigger than the values for other constructs (loadings greater than 0.1) and the square root of the AVE for each component is greater than the differences between pairs of constructs and is above 0.5., discriminant validity occurs [61]. In this research, the AVE values vary between 0.610 and 0.639 , which is acceptable. Moreover, the heterotrait-monotrait ratio (HTMT) assesses the discriminant validity of the partial least square structural equation model (PLS-SEM). Therefore, Table 2 presents the HTMT values between reflective constructs that are below the commonly accepted criteria of 0.90 [62].

Table 2. Results of the heterotrait-monotrait Ratio (HTMT) of correlations.

\begin{tabular}{cccc}
\hline & Employability & Job Insecurity & Moderating Effect \\
\hline Job Insecurity & 0.542 & & \\
Moderating Effect & 0.089 & 0.149 & \\
Work Engagement & 0.652 & 0.620 & 0.223 \\
\hline
\end{tabular}

\subsection{Assessment of the Structural Model}

According to Baron and Kenny (1986) [63], moderation is to "measure and test the differential effect of the independent variable on the dependent variable as a function of the moderator." As was found using SmartPLS3, job insecurity moderates the direct relationship between employability and work engagement. In our study, we used a basic structural model consisting of work engagement as a dependent variable, employability as an independent variable, and job insecurity as a moderator variable.

The following section will provide the results considering the testing of the hypotheses compared to the main effects. This research applied the partial least squares (PLS) technique by utilizing standard bootstrapping with several 5000 samples and 185 cases to understand and compare the importance of the path values [64] (see Table 3).

Table 3. Structural model assessment with moderation.

\begin{tabular}{lcccccc}
\hline & Hypothesis & Beta & Mean & Standard Deviation & T-Value & $p$ Values \\
\hline H1 & Employability $\rightarrow$ WE & 0.355 & 0.357 & 0.071 & 5.021 & 0.000 \\
H2 & JIS $\rightarrow$ WE & 0.416 & 0.418 & 0.065 & 6.379 & 0.000 \\
H3 & Moderating Effect $\rightarrow$ WE & -0.19 & -0.181 & 0.077 & 2.477 & 0.013 \\
\hline
\end{tabular}

As shown in Table 4, the highest correlation value is 0.45 (between perceived employability and work engagement). The symbol "***" indicates significance at the 0.01 level, which is in line with our hypothesis (H1). On other counts, job insecurity denoted a direct negative correlation with perceived employability at $-0.34^{* *}(p<0.01$ level), as was hypothesized (i.e., H2). Meanwhile, the Pearson correlation extraction depicted a significant and negative correlation between job insecurity and work engagement at $-0.27^{* *}$, as was hypothesized (H3). 
Table 4. Means, standard deviations, and correlations of variables.

\begin{tabular}{|c|c|c|c|c|c|c|c|c|c|}
\hline Variables & Mean & $\begin{array}{l}\text { Standard } \\
\text { Deviation }\end{array}$ & Age & Gender & Education & Tenure & $\begin{array}{c}\text { Perceived } \\
\text { Employability }\end{array}$ & $\begin{array}{c}\text { Job } \\
\text { Insecurity }\end{array}$ & $\begin{array}{c}\text { Work } \\
\text { Engagemen }\end{array}$ \\
\hline Age & 1.70 & 0.79 & 1 & & & & & & \\
\hline Gender & 0.44 & 0.48 & -0.12 & 1 & & & & & \\
\hline Education & 3.44 & 0.82 & $0.25^{* *}$ & 0.16 & 1 & & & & \\
\hline Tenure & 1.75 & 0.61 & 0.38 & 0.08 & -0.11 & 1 & & & \\
\hline Perceived & 4.02 & 0.79 & 0.16 & 0.29 & -0.09 & 0.11 & 1 & & \\
\hline Employability & & & & & & & & 1 & \\
\hline Job Insecurity & 3.25 & 1.06 & 0.18 & 0.36 & 0.32 & 0.14 & $-0.34^{* *}$ & & \\
\hline $\begin{array}{c}\text { Work } \\
\text { Engagement }\end{array}$ & 4.57 & 1.25 & 0.16 & 0.11 & -0.29 & 0.07 & $0.45 * *$ & $\begin{array}{c}-0.27^{* *} \\
1\end{array}$ & \\
\hline
\end{tabular}

** Correlation is significant at the 0.01 level (2-tailed Pearson Correlation).

\subsection{Moderating Effect of Job Insecurity}

Job insecurity is introduced as a moderator variable in this research. Job insecurity is assumed to negatively affect the link between employability and work engagement. The findings also show that the higher the influence of job insecurity, the weaker the link between employability and work engagement. Utilizing 5000 samples in the two-step bootstrapping approach with SmartPLS 3, the moderating effect of job insecurity was analyzed [65].

Simple slope analysis for understanding the moderation effect was also used in SmartPLS 3. The relationship between employability and work engagement is positive for all three lines, as indicated by their positive slopes in Figure 2. Hence, lower levels of employability are associated with lower levels of work engagement. The line (in blue) that represents a lower level of the moderator (job insecurity) has a flatter slope, while the line (in green) representing a higher level of the moderator has a steeper slope. The simple slope plot shows the negative interaction term: Lower job insecurity levels demand a stronger relationship between employability and work engagement, and vice-versa.

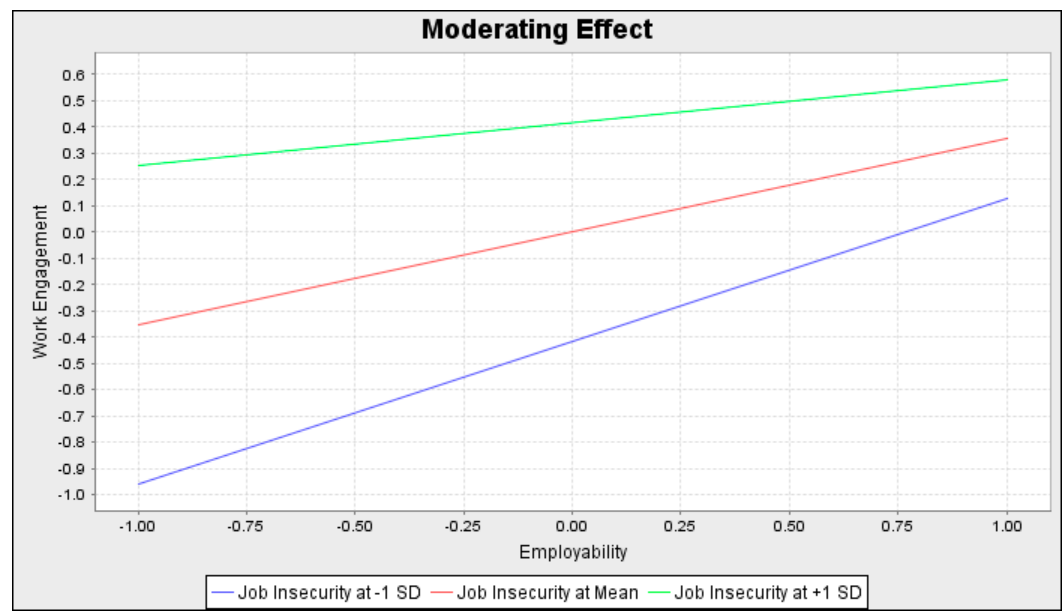

Figure 2. Moderating effect.

\section{Discussion and Conclusions}

In this research, we suggested and tested a research model that investigates the effect of perceived employability on organizational well-being, as well as the moderating effect of job insecurity on the relationship between perceived employability and work engagement, via data gathered from employees working in five-star hotels in Northern Cyprus. All of the relationships proposed in our study were supported by the empirical data. The research findings offer important insights concerning the abovementioned relations.

According to the JD-R model, and assuming that perceived employability is an individual resource, it follows that perceived employability is related to employee well-being. 
Therefore, according to the results, we established that employability was associated with well-being: Employability was positively related to engagement (H1), that is, an outcome outside the workplace, which suggests that employability may be a powerful predictor. Still, not much variance could be attributed to employability, possibly because well-being is a fairly broad concept that is predicted by many other variables, or because employability prevents the development of negative experiences, such as unemployment or feelings of being locked in. This idea of employability as a prevention tool does not imply strongly favorable correlates; employability may have the potential to reduce negative feelings rather than to induce positive feelings.

In addition, in our second hypothesis (H2), we argued that perceived employability is negatively associated with job insecurity, which is supported according to our results. Employees are dedicated to the idea of long-term secure employment as a return for human capital investments. Moreover, employees are expected to look for employment security rather than job stability, which means that employees establish employment stability by moving across organizational boundaries and from one job to the next, rather than staying within a single organization or job [37]. In this regard, employment security is conditioned by employees' employability, which is in line with the study from [15].

Job insecurity, as a hindrance stressor, impedes the learning of employees and hinders their growth and development [42]. In such situations, workers have a low degree of dedication to their work. Our finding concerning the influence of job insecurity on work engagement is in line with the findings in the works of $[13,66,67]$.

Besides, in comparison with the work of [13], which predicted that job insecurity acts as a mediator between employability and employee well-being, this study focused on job insecurity by hypothesizing it as a moderator. Our empirical findings support our claim, which is a support for our proposed H3 and H4. Our study thus unfolds the different roles performed by perceived employability and job insecurity and also demonstrates the impact of perceived employability on work-related outcomes.

To conclude, employability is a personal resource that has been mostly dealing with different demands, such as job insecurity and work- and life-related variations. According to the literature, perceived employability helps employees deal with workplace uncertainty, which is known as job insecurity $[37,38]$, in such a manner that employability increases the sense of being in charge of one's life, which, in turn, decreases the negative consequences of work instability [23].

Also, it is has been discussed by [32] that "highly employable workers may perceive a situation that leads to job insecurity as less threatening than less employable workers." this clarifies that, as a resource, employability is expected to decrease employees' job insecurity or the fear of not having employment chances, and it has been claimed to provide people with a sense of autonomy and to make them more likely to achieve participation at work [13].

\subsection{Managerial Implications}

Our study suggests some practical implications for managers. In thinking about a sustainable tourism market environment, job insecurity is a fact, especially in the Northern Cyprus hotel industry. Thus, companies must reduce workers' perception of job insecurity. When they feel more secure at work, the positive impact of perceived employability on work engagement can be better accomplished, and they will participate more in their jobs. The management of the hotels should consider all stakeholder groups in the process of decision-making for their organization. In particular, as an important social characteristic of organizational sustainability, job security should be provided to all employees who perform their tasks properly according to the requirements of the organization. Based on our findings, managers should also seek to facilitate and enhance perceived employability for employees. The value of employability is manifested in developing professional skills and professional involvement and reducing the perception of job insecurity, especially in the tourism industry, which has a delicate and sensitive structure.

To enrich employees' work engagement, the management should support the dedication of workers to their work. To do this, managers can organize monthly meeting sessions and show 
appreciation to highly dedicated and successful employees of that month. Meanwhile, they can ask employees to discuss and give their feedback about the factors that trigger their intention to be more engaged and motivated while working. Gathering this information from employees will be helpful for managers to find better solutions for employees to remain devoted and loyal to their work.

\subsection{Limitations and Further Research}

Nevertheless, a set of shortcomings in our research should be noted. Given that little research is accessible on the position of perceived employability in non-Western nations, this analysis strengthens our comprehension in this regard by utilizing samples from Northern Cyprus. It is worth noting that according to our results, employee reactions to perceived employability in terms of work engagement are similar to those of employees in certain Western countries. Further cross-cultural research will be conducted in such a way as to check the applicability of this paradigm in certain contexts. Second, the cross-section of our research addresses the question of causality. The causal relation between perceived employability and work engagement cannot be readily identified. A longitudinal study that lets researchers assess the causal path and the mutual association between test variables is also desirable.

Moreover, to be able to capture another angle of employability, its influence, and its role, other authors could examine it as a mediator/moderator. Besides, other variables such as emotional intelligence could be implemented as a more acute subjective variable in place of employability. Moreover, since perceived employability can reduce employees' negative feelings, emotions, and consequences, then variables like burnout, exhaustion, cynicism, or service sabotage can be used as an outcome of perceived employability to display the abovementioned relationship well. This is to say that the limitations of our model design and survey methods should be side-stepped in future studies.

Another shortcoming of this method lies in the use of self-report questionnaires. For instance, the possibilities of common method bias could inflate the results, alter the correlations, or may even be the cause of low loadings, as some items were forced to be dropped along the way. Another study could probably utilize other methods to eliminate bias, like the use of time-lapse-like [54] time interims, or drawing a response from all hotel workers and increasing the number of responses, instead of just the frontline ones, just to avoid selection bias. Again, the use of interviews alongside self-report questionnaires is a fine way to extend the study and obtain more results.

Author Contributions: N.N.A. completed the introduction and theoretical background and wrote the methodology and results sections. H.A. contributed to reviewing the recent literature and checked the last version of the paper. Both authors wrote the discussion and results sections and checked the latest version of the paper. Both authors have read and agreed to the published version of the manuscript.

Funding: This research received no external funding.

Conflicts of Interest: The authors declare no conflict of interest.

\section{References}

1. Ozkoc, A.G.; Caliskan, N. The Changing Nature of Psychological Contract in the Tourism Industry: Importance of Employability. In Organizational Behavior Challenges in the Tourism Industry; IGI Global: Hershey, PA, USA, 2020; pp. 168-187.

2. Bozionelos, N.; Kostopoulos, K.; Van der Heijden, B.; Rousseau, D.M.; Bozionelos, G.; Hoyland, T.; Miao, R.; Marzec, I.; Jedrzejowicz, P.; Epitropaki, O.; et al. Employability and job performance as links in the relationship between mentoring receipt and career success: A study in SMEs. Group Organ. Manag. 2016, 41, 135-171. [CrossRef]

3. Vanhercke, D.; De Cuyper, N.; Peeters, E.; De Witte, H. Defining perceived employability: A psychological approach. Pers. Rev. 2014, 43, 592-605. [CrossRef]

4. De Cuyper, N.; Sulea, C.; Philippaers, K.; Fischmann, G.; Iliescu, D.; De Witte, H. Perceived employability and performance: Moderation by felt job insecurity. Pers. Rev. 2014, 43, 536-552. [CrossRef] 
5. Malik, P.; Garg, P. Learning organization and work engagement: The mediating role of employee resilience. Int. J. Hum. Resour. Manag. 2020, 31, 1071-1094. [CrossRef]

6. Karatepe, O.M.; Rezapouraghdam, H.; Hassannia, R. Job insecurity, work engagement, and their effects on hotel employees' non-green and nonattendance behaviors. Int. J. Hosp. Manag. 2020, 87, 102472. [CrossRef]

7. Economy. Available online: https://pio.mfa.gov.ct.tr/en/economy/ (accessed on 1 December 2020).

8. Arasli, H.; Arici, H.E.; Çakmakoğlu Arici, N. Workplace favoritism, psychological contract violation, and turnover intention: Moderating roles of authentic leadership and job insecurity climate. Ger. J. Hum. Resour. Manag. 2019, 33, 197-222. [CrossRef]

9. Chiu, S.F.; Peng, J.C. The relationship between psychological contract breach and employee deviance: The moderating role of hostile attributional style. J. Vocat. Behav. 2008, 73, 426-433. [CrossRef]

10. Vander Elst, T.; De Witte, H.; De Cuyper, N. The Job Insecurity Scale: A psychometric evaluation across five European countries. Eur. J. Work Organ. Psychol. 2014, 23, 364-380. [CrossRef]

11. Tian, Q.; Zhang, L.; Zou, W. Job insecurity and counterproductive behavior of casino dealers-the mediating role of affective commitment and the moderating role of supervisor support. Int. J. Hosp. Manag. 2014, 40, 29-36. [CrossRef]

12. Schaufeli, W.B.; Salanova, M.; Gonzáles-Romá, V.; Bakker, A.B. The measurement of engagement and burnout: A two sample confirmatory factor analytic approach. J. Happiness Stud. 2002, 3, 71-92. [CrossRef]

13. Cuyper, N.D.; Bernhard-Oettel, C.; Berntson, E.; Witte, H.D.; Alarco, B. Employability and employees' well-being: Mediation by job insecurity 1. Appl. Psychol. 2008, 57, 488-509. [CrossRef]

14. Hellgren, J.; Sverke, M. Does job insecurity lead to impaired well-being or vice versa? Estimation of cross-lagged effects using latent variable modeling. J. Organ. Behav. 2003, 24, 215-236. [CrossRef]

15. Ngo, H.Y.; Liu, H.; Cheung, F. Perceived employability of Hong Kong employees: Its antecedents, moderator, and outcomes. Pers. Rev. 2017, 46, 17-35. [CrossRef]

16. Wittekind, A.; Raeder, S.; Grote, G. A longitudinal study of determinants of perceived employability. J. Organ. Behav. 2010, 31, 566-586. [CrossRef]

17. Crawford, E.R.; LePine, J.A.; Rich, B.L. Linking job demands and resources to employee engagement and burnout: A theoretical extension and meta-analytic test. J. Appl. Psychol. 2010, 95, 834. [CrossRef]

18. Podsakoff, P.M.; MacKenzie, S.B.; Lee, J.Y.; Podsakoff, N.P. Common method biases in behavioral research: A critical review of the literature and recommend remedies. J. Appl. Psychol. 2003, 88, 879-903. [CrossRef]

19. Bernstrøm, V.H.; Drange, I.; Mamelund, S.E. Employability as an alternative to job security. Pers. Rev. 2019, 48, 234-248. [CrossRef]

20. De Cuyper, N.; De Witte, H.; Kinnunen, U.; Nätti, J. The relationship between job insecurity and employability and well-being among Finnish temporary and permanent employees. Int. Stud. Manag. Organ. 2010, 40,57-73. [CrossRef]

21. Berntson, E.; Marklund, S. The relationship between perceived employability and subsequent health. Work Stress 2007, 21, 279-292. [CrossRef]

22. Berntson, E.; Sverke, M.; Marklund, S. Predicting perceived employability: Human capital or labor market opportunities. Econ. Ind. Democr. 2006, 27, 223-244. [CrossRef]

23. Fugate, M.; Kinicki, A.J.; Ashforth, B.E. Employability: A psycho-social construct, its dimensions, and applications. J. Vocat. Behav. 2004, 65, 14-38. [CrossRef]

24. Feldman, D.C.; Ng, T.W. Careers: Mobility, embeddedness, and success. J. Manag. 2007, 33, $350-377$. [CrossRef]

25. Magnano, P.; Santisi, G.; Zammitti, A.; Zarbo, R.; Di Nuovo, S. Self-perceived employability and meaningful work: The mediating role of courage on quality of life. Sustainability 2019, 11, 764. [CrossRef]

26. De Bruin, A.; Dupuis, A. Making Employability 'Work'. J. Interdiscip. Econ. 2008, 19, 399-419. [CrossRef]

27. Olson, D.A.; Shultz, K.S. Employability and career success: The need for comprehensive definitions of career success. Ind. Organ. Psychol. 2013, 6, 17-20. [CrossRef]

28. Noe, R.A.; Hollenbeck, J.R.; Gerhart, B.; Wright, P.M. Human Resource Management: Gaining a Competitive Advantage; McGraw-Hill Education: New York, NY, USA, 2017.

29. Pardo-Garcia, C.; Barac, M. Promoting Employability in Higher Education: A Case Study on Boosting Entrepreneurship Skills. Sustainability 2020, 12, 4004. [CrossRef]

30. Demerouti, E.; Bakker, A.B.; Nachreiner, F.; Schaufeli, W.B. The job demands-resources theory of burnout. J. Appl. Psychol. 2001, 86, 499-512. [CrossRef] 
31. Bakker, A.B.; Demerouti, E.; Verbeke, W. Using the job demands-resources model to predict burnout and performance. Hum. Resour. Manag. 2004, 43, 83-104. [CrossRef]

32. De Cuyper, N.; Notelaers, G.; De Witte, H. Job insecurity and employability in fixed-term contractors, agency workers, and permanent workers: Associations with job satisfaction and affective organizational commitment. J. Occup. Health Psychol. 2009, 14, 193. [CrossRef]

33. Jackson, D.; Tomlinson, M. Investigating the relationship between career planning, proactivity and employability perceptions among higher education students in uncertain labor market conditions. High. Educ. 2020, 80, 435-455. [CrossRef]

34. Karatepe, O.M.; Ngeche, R.N. Does job embeddedness mediate the effect of work engagement on job outcomes? A study of hotel employees in Cameroon. J. Hosp. Mark. Manag. 2012, 21, 440-461. [CrossRef]

35. Schaufeli, W.B.; Taris, T.W. A critical review of the job demands-resources model: Implications for improving work and health. In Bridging Occupational, Organizational, and Public Health; Springer: Dordrecht, The Netherlands, 2014; pp. 43-68.

36. Demerouti, E.; Bakker, A.B. The job demands-resources model: Challenges for future research. $S A J$. Ind. Psychol. 2011, 37, 1-9. [CrossRef]

37. Forrier, A.; Sels, L. The concept employability: A complex mosaic. Int. J. Hum. Resour. Dev. Manag. 2003, 3, 102-124. [CrossRef]

38. Sverke, M.; Hellgren, J.; Näswall, K. No security: A meta-analysis and review of job insecurity and its consequences. J. Occup. Health Psychol. 2002, 7, 242. [CrossRef]

39. Bakker, A.B.; Demerouti, E. The job demands-resources model: State of the art. J. Manag. Psychol. 2007, 22, 309-328. [CrossRef]

40. Elman, C.; O'Rand, A.M. Perceived labor market insecurity and the educational participation of workers at midlife. Soc. Sci. Res. 2002, 31, 49-76. [CrossRef]

41. Silla, I.; De Cuyper, N.; Gracia, F.J.; Peiro, J.M.; De Witte, H. Job insecurity and well-being: Moderation by employability. J. Happiness Stud. 2009, 10, 739. [CrossRef]

42. Folkman, S.; Lazarus, R.S. Stress, Appraisal, and Coping; Springer Publishing Company: New York, NY, USA, 1984; pp. 150-153.

43. Wang, H.J.; Lu, C.Q.; Siu, O.L. Job insecurity and job performance: The moderating role of organizational justice and the mediating role of work engagement. J. Appl. Psychol. 2015, 100, 1249. [CrossRef]

44. Probst, T.M. Development and validation of the Job Security Index and the Job Security Satisfaction scale: A classical test theory and IRT approach. J. Occup. Organ. Psychol. 2003, 76, 451-467. [CrossRef]

45. Ashford, S.J.; Lee, C.; Bobko, P. Content, cause, and consequences of job insecurity: A theory-based measure and substantive test. Acad. Manag. J. 1989, 32, 803-829.

46. Kim, M.J.; Kim, B.J. Analysis of the Importance of Job Insecurity, Psychological Safety, and Job Satisfaction in the CSR-Performance Link. Sustainability 2020, 12, 3514. [CrossRef]

47. Chiesa, R.; Fazi, L.; Guglielmi, D.; Mariani, M.G. Enhancing sustainability: Psychological capital, perceived employability, and job insecurity in different work contract conditions. Sustainability 2018, 10, 2475. [CrossRef]

48. Park, K.H.; Youn, S.J.; Moon, J. The Effect of Workforce Restructuring on Withdrawal Behavior: The Role of Job Insecurity, Career Plateau, and Procedural Justice. J. Asian Financ. Econ. Bus. 2020, 7, 413-424. [CrossRef]

49. Imam, H.; Chambel, M.J. Productivity or illusion? Assessing employees' behavior in an employability paradox. Empl. Relat. Int. J. 2020, 42, 1271-1289. [CrossRef]

50. De Cuyper, N.; Van der Heijden, B.I.; De Witte, H. Associations between perceived employability, employee well-being, and its contribution to organizational success: A matter of psychological contracts. Int. J. Hum. Resour. Manag. 2011, 22, 1486-1503. [CrossRef]

51. Podsakoff, P.M.; MacKenzie, S.B.; Podsakoff, N.P. Sources of method bias in social science research and recommendations on how to control it. Annu. Rev. Psychol. 2012, 63, 539-569. [CrossRef]

52. Jakobsen, M.; Jensen, R. Common method bias in public management studies. Int. Public Manag. J. 2015, 18, 3-30. [CrossRef]

53. De Cuyper, N.; Mauno, S.; Kinnunen, U.; Mäkikangas, A. The role of job resources in the relation between perceived employability and turnover intention: A prospective two-sample study. J. Vocat. Behav. 2011, 78, 253-263. [CrossRef]

54. Schaufeli, W.B.; Bakker, A.B.; Salanova, M. The measurement of work engagement with a short questionnaire: A cross-national study. Educ. Psychol. Meas. 2006, 66, 701-716. [CrossRef] 
55. Parameswaran, R.; Yaprak, A. A cross-national comparison of consumer research measures. J. Int. Bus. Stud. 1987, 18, 35-49. [CrossRef]

56. Sarstedt, M.; Ringle, C.M.; Smith, D.; Reams, R.; Hair, J.F., Jr. Partial least squares structural equation modeling (PLS-SEM): A useful tool for family business researchers. J. Fam. Bus. Strategy 2014, 5, 105-115. [CrossRef]

57. Sun, J.Q.; Zhang, R.Y.; Liu, Z.P.; Lu, G.H. Thermal reliability test of Al-34\% Mg-6\% Zn alloy as latent heat storage material and corrosion of metal with respect to thermal cycling. Energy Convers. Manag. 2007, 48, 619-624. [CrossRef]

58. Peterson, R.A.; Kim, Y. On the relationship between coefficient alpha and composite reliability. J. Appl. Psychol. 2013, 98, 194. [CrossRef]

59. Bagozzi, R.P.; Yi, Y. On the evaluation of structural equation models. J. Acad. Mark. Sci. 1988, 16, 74-94. [CrossRef]

60. Hair, J.F.; Ringle, C.M.; Sarstedt, M. PLS-SEM: Indeed a silver bullet. J. Mark. Theory Pract. 2011, 19, $139-152$. [CrossRef]

61. Chin, W.W. Commentary: Issues and Opinion on Structural Equation Modeling. MIS Quart. 1998, 22, vii-xvi.

62. Fornell, C.; Larcker, D.F. Evaluating structural equation models with unobservable variables and measurement error. J. Mark. Res. 1981, 18, 39-50. [CrossRef]

63. Henseler, J.; Ringle, C.M.; Sarstedt, M. A new criterion for assessing discriminant validity in variance-based structural equation modeling. J. Acad. Mark. Sci. 2015, 43, 115-135. [CrossRef]

64. Baron, R.M.; Kenny, D.A. The moderator-mediator variable distinction in social psychological research: Conceptual, strategic, and statistical considerations. J. Personal. Soc. Psychol. 1986, 51, 1173. [CrossRef]

65. Hair, J.F., Jr.; Sarstedt, M.; Hopkins, L.; Kuppelwieser, V.G. Partial least squares structural equation modeling (PLS-SEM). Eur. Bus. Rev. 2014, 26, 106-121. [CrossRef]

66. Hair, J.F.; Risher, J.J.; Sarstedt, M.; Ringle, C.M. When to use and how to report the results of PLS-SEM. Eur. Bus. Rev. 2019, 31, 2-24. [CrossRef]

67. De Spiegelaere, S.; Van Gyes, G.; De Witte, H.; Niesen, W.; Van Hootegem, G. On the relation of job insecurity, job autonomy, innovative work behavior, and the mediating effect of work engagement. Creat. Innov. Manag. 2014, 23, 318-330. [CrossRef]

Publisher's Note: MDPI stays neutral with regard to jurisdictional claims in published maps and institutional affiliations.

(C) 2020 by the authors. Licensee MDPI, Basel, Switzerland. This article is an open access article distributed under the terms and conditions of the Creative Commons Attribution (CC BY) license (http://creativecommons.org/licenses/by/4.0/). 